\title{
MODEL DISTRIBUSI POTENSI KEMASAMAN TAMBAK TANAH SULFAT MASAM PADA LAPISAN KEDALAMAN TERTENTU
}

\author{
Tarunamulia"), Abdul Malik Tangko"), dan Adi Hanafi")
}

\begin{abstract}
ABSTRAK
Upaya pemanfaatan lahan marginal khususnya tambak-tambak yang berasosiasi dengan tanah sulfat masam akan menghadapi permasalahan yang cukup kompleks dengan berbagai perlakuan dalam kegiatan budi daya tambak yang mengarah pada pengangkatan material dasar yang memiliki potensi kemasaman tinggi. Penelitian ini bertujuan untuk mengetahui model distribusi potensi kemasaman pada suatu lapisan kedalaman tertentu dengan membandingkan dua model pendekatan: pertama dengan asumsi pengambilan lapisan kedalaman sampel homogen terhadap pelataran tambak, kedua adalah kedalaman sampel homogen terhadap suatu datum referensi yang diukur secara lokal dengan memanfaatkan analisis harmonik pasang surut (MSL lokal). Data diukur pada suatu rentang kedalaman yang berstruktur kemudian dikelompokkan berdasarkan kedua metode pendekatan tersebut, selanjutnya diolah dengan program statistik khusus pemetaan (SURFER) untuk mengetahui model distribusi dan program statistik umum (SPSS) untuk analisis deskriptif dan uji korelasi. Hasil yang diperoleh menunjukan bahwa kedua model yang dibandingkan tidak menunjukkan perbedaan nyata dalam menentukan distribusi potensi kemasaman, perbedaan yang menonjol hanya dapat dilihat pada data yang memiliki letak vertikal di atas MSL, hal ini diperkuat dari hasil analisis statistik yang menunjukan korelasi yang signifikan untuk uji dua sisi pada kedua tingkat kepercayaan $(0,01$ dan 0,05$)$ meskipun nilai korelasi hampir semua menyatakan bahwa hubungan tersebut tidak kuat. Perbedaan yang mengakibatkan nilai korelasi lemah terjadi terutama karena adanya beda letak vetikal sampel tanah dari perbedaan referensi pengukuran. Kecenderungan dengan adanya perbedaan nilai tersebut harus menjadi perhatian dalam pengambilan sampel tanah, khususnya pada wilayah pesisir yang memiliki tingkat kemiringan yang tinggi dengan tunggang pasang surut yang rendah.
\end{abstract}

\begin{abstract}
Potential acidity distribution models at acid sulfate soil affected ponds to a certain depth layer. By: Tarunamulia, Abdul Malik Tangko, and Adi Hanafi
\end{abstract}

The development of aquaculture ponds in acid sulfate soil affected coastal plains and wetlands will encounter complex and serious problems due to the influence of some activities (eg. dredging, excavation, and drainage) on pyrite oxidation. Pond construction and maintenance can expose horizontal layers of pyrite accumulated during the sedimentary evolution of the Holocene landscape. Consequently, large amounts of acid, and toxic metals may be released. This research was aimed at describing the distribution models of potential acidity in acid sulfate soil affected ponds at a certain depth $(0-20 \mathrm{~cm})$, based on two approaches of measuring reference datum. The first approach assumed that soil sample could be considered to have a homogenous position if it was measured from pond bottom and the second approach considered the positions of ponds (soil sample) which is varied due to diffrence of topographic condition, so that it should be referred to an exact datum level such as mean sea level (MSL) calculated from tidal harmonic constituents. The research was carried out by classifying the data into two groups with regard to the two approaches, then analyzed using statistical mapping (SURFER) describing the distribution models of potentials acidity and for correlation analysis purposes was conducted in SPSS (statistical computer software for general purposes). The results showed a significant correlation at the 0.01 and 0.05 confidence levels (2-tailed) of both the two models, despite of Pearson correlation indicated a week correlation value. The difference was mainly caused by vertical position of a part of soil sample, which was different from measurement reference datum created. The existing trend should be carefully learnt for further implementation of the survey in order to reduce the distinct error (will occurred) in soil sampling where the topographics of survey area are slope sharply.

KEYWORDS: $\quad$ potential acidity, distribution models, depth layer 


\section{PENDAHULUAN}

Kegiatan konstruksi dalam upaya pemanfaatan lahan marginal tambak-tambak yang berasosiasi dengan tanah sulfat masam akan menghadapi permasalahan yang cukup kompleks terutama dalam hal pembukaan lahan baru, penggalian tambak, dan peninggian pematang dari tanah hasil galian tersebut serta kegiatan-kegiatan penggunaan lahan lain di sekitar tambak yang mengarah pada penggalian dan pengarigkatan material dasar. Kegiatan tersebut tanpa disadari akan membangkitkan potensi kemasaman dari pyrit yang terdapat pada lapisan kedalaman tertentu dalam tanah yang sangat membahayakan usaha budi daya.

Pyrit terbentuk pada kondisi lahan terendarn total, sedimen salin yang mengandung besi dan cukup tersedianya sumber bahan organik yang terurai (DLWC, 1995). Bakteri menguraikan bahan organik pada kondisi anaerob dan mereduksi sulfat menjadi sulfida (Pons et al., 1982). Hasil akhir dari proses ini adalah pyrit yang dikenal sebagai potensi tanah sulfat masam.

Upaya yang dilakukan untuk mengantisipasi keberadaan potensi kemasaman pada tambak tanah sulfat masarn telah banyak dipraktekkan, namun pada kenyataannya hasil yang diperoleh belum pada taraf maksimal. Hal ini kemungkinan besar disebabkan informasi tentang letak lapisan (vertikal dan horizontal) yang berpotensi membangkitkan kemasaman belum jelas sehingga aplikasi teknologi seperti teknik remediasi akan mengalami hambatan dalam menetapkan model perlakuan dan kalkulasi bahan baku untuk menetralkan potensi kemasaman tersebut.

Oleh karena itu, kegiatan pemetaan dengan berbagai model pendekatan yang diarahkan pada penemuan model distribusi potensi kemasaman yang bersifat praktis dan didukung oleh pendekatan teoritis akan sangat membantu kegiatan pemanfaatan dan pengelolaan tambak tanah sulfat masam. Penelitian ini bertujuan untuk mengetahui model distribusi potensi kemasaman lahan tambak pada tambak tanah sulfat masam dengan membandingkan dua model pendekatan yang mengacu pada datum referensi vertikal yang berbeda.

\section{BAHAN DAN METODE}

Lokasi penelitian terletak pada kawasan tambak terletak pada $120^{\circ} 15^{\prime} 31,72^{\prime \prime}-120^{\circ} 16^{\prime} 40,6^{\prime \prime}$ Bujur Timur dan $5^{\circ} 8^{\prime} 26,72^{\prime \prime}-5^{\circ} 7^{\prime} 42^{\prime \prime}$ Lintang Selatan, merupakan wilayah pesisir yang terletak di pantai timur Sulawesi Selatan tepatnya di Kecamatan Sinjai Timur, Kabupaten Sinjai (Gambar 1). Luas tambak yang disurvai \pm 50 ha, dengan luasan per petak berkisar 0,09 ha hingga 1 ha (rata-rata $0,30 \mathrm{ha}$ ).
Penelitian ini terdiri atas kegiatan lapangan, kegiatan laboratorium, dan analisis data. Kegiatan lapangan meliputi: penentuan datum referensi, pengukuran kerangka vertikal dan horizontal, serta penentuan titik sampling serta sampling tanah. Sedangkan kegiatan laboratorium berupa analisis beberapa peubah kimia tanah yang akan digunakan sebagai data base untuk menunjukkan tingkat potensi kemasaman tanah pada tambak tanah sulfat masam.

\section{Kegiatan Lapangan}

Penetapan datum referensi: untuk kebutuhan praktis, datum referensi yang digunakan adalah duduk tengah sementara dari hasil pengukuran pasang surut (pasut) dengan periode pengamatan selama 39 jam yang diikatkan pada bench mark (BM) yang memiliki posisi horizontal (sistem koordinat lokal). Sedangkan untuk kebutuhan analisis lanjutan, data tersebut dipadukan dengan data ramalan pasut tahunan yang dikeluarkan oleh Dinas Hidro Oseanografi (Dishidros) pada lokasi yang berdekatan dan memiliki karakteristik pasang surut yang sama. Sebelum dilakukan perhitungan beberapa permukaan penting pasut untuk dijadikan datum referensi vertikal maka terlebih dahulu dilakukan penentuan tipe pasang surut dengan menggunakan bilangan formzhal (Pugh, 1987) sebagai berikut:

$$
F=\frac{(A O 1+A K 1)}{(A M 2+A S 2)}
$$

Di mana:

AO1 = Komponen utama diurnal bulan Amplitude of principal lunar diurnal component

AK1 = Komponen matahari-bulan Amplitude of luni-solar diurnal component

AM2 = Komponen utama semidiurnal bulan Amplitude of principal lunar semidiurnal components

AS2

= Komponen utama semidiurnal matahari Amplitude of principal solar semidiurnal components

Adapun kriteria untuk kisaran nilai $F$ adalah :

$0-0.25=$ Pasut bertipe ganda (Semidiurnal type)

$0.26-1.50=$ Pasut bertipe campuran dengan tipe ganda lebih menonjol (Mixed type, semidiurnal dominance)

$1.6-3.00=$ Pasut bertipe campuran dengan tipe tunggal lebih menonjol (Mixed type, diurnal dominance)

$>3.00=$ Pasut bertipe tunggal (Diurnal type) 


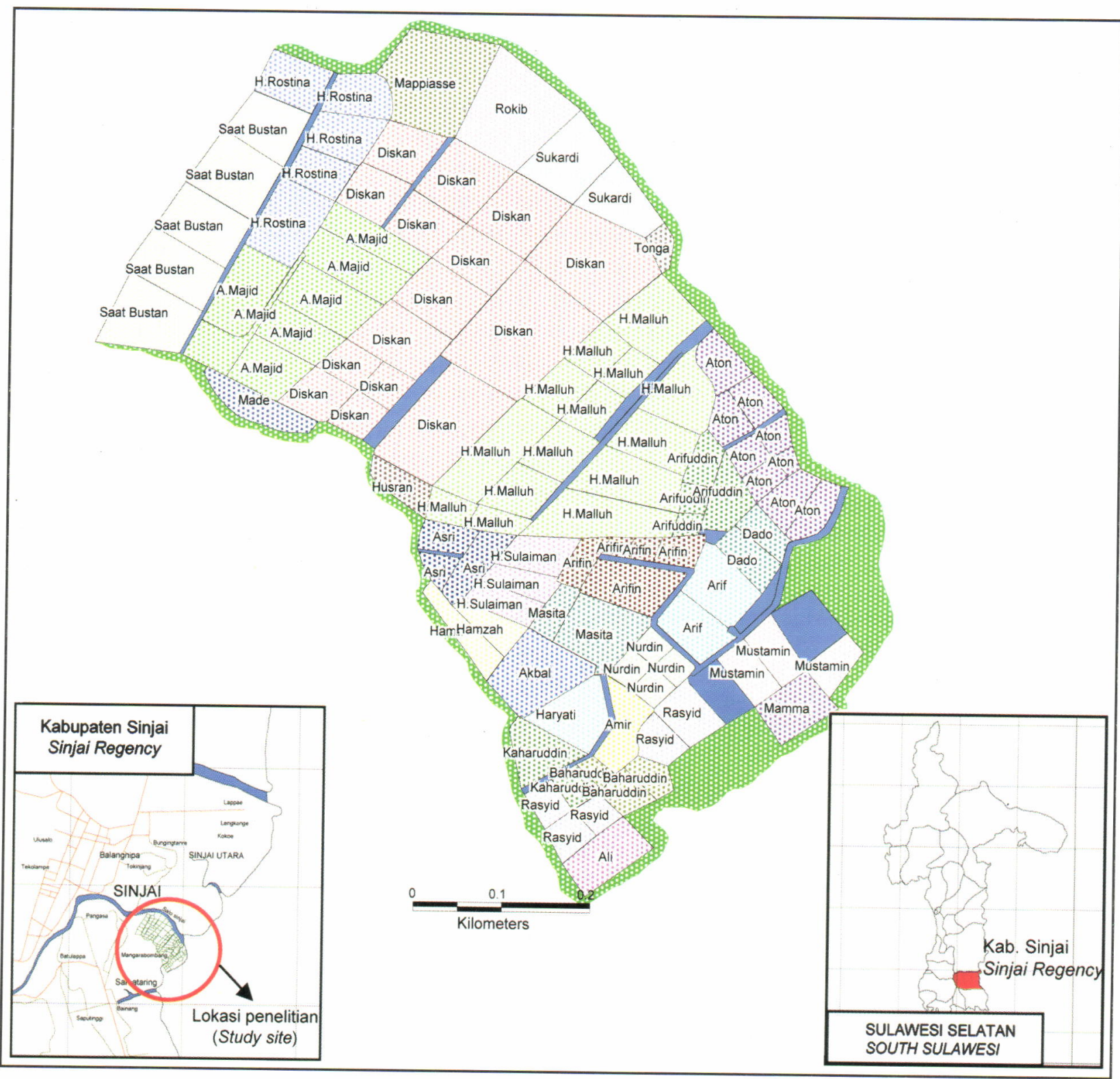

Gambar 1. Peta lokasi penelitian di Kecamatan Sinjai Timur, Kabupaten Sinjai Figure 1. Map of study site in East Sinjai District, Sinjai Regency

- Pengukuran kerangka horizontal: dilakukan untuk menggambarkan sistem penggunaan lahan pada areal pertambakan dan membatasi areal survai. Metode pengukuran yang diterapkan adalah metode poligon.

- Pengukuran kerangka vertikal: dilaksanakan dengan metode sipat datar memanjang dan profil melintang, untuk menentukan beda tinggi antara titik sampling (dasar tambak).

- Penentuan titik sampling dan sampling tanah: titik sampling ditentukan dengan metode stratified random sampling yang merupakan perpaduan antara sampling teratur (regular sampling) dan sampling acak (random sampling). Contoh tanah diambil dengan menggunakan bor tangan pada tiap dasar tambak untuk berbagai kedalaman, selanjutnya dilakukan analisis kimia untuk masing-masing sampel tanah dengan mengukur $\mathrm{pH}_{\mathrm{F}}(\mathrm{pH}$ yang terukur langsung di lapangan dengan menggunakan $\mathrm{pH}$-meter), $\mathrm{pH}_{\text {FOX }}(\mathrm{pH}$ yang terukur di lapangan setelah sampel tanah segar dioksidasi dengan $\mathrm{H}_{2} \mathrm{O}_{2}$ ), potensial redoks, dan reaksi peroksida.

\section{Kegiatan Laboratorium}

Kegiatan laboratorium meliputi analisis beberapa variabel spesifik kimia tanah yang dapat menjadi indikator potensi kemasaman pada tambak tanah sulfat masam, seperti: $\mathrm{pH}_{\mathrm{ox}}$, TPA (Total Potensi 
Kemasaman), STPA (Total Potensi Kemasaman yang disebabkan oleh Sulfur) dan \% Pyrit $\left(\mathrm{FeS}_{2}\right)$. Prosedur analisis contoh tanah mengacu pada metode POCAS (Peroxide Oxidation Combined Acidity \& Sulfate) (Ahern \& Blunden, 1998).

\section{HASIL DAN BAHASAN}

\section{Kondisi Umum Tambak}

Kondisi topografi tambak-tambak yang disurvai $70 \%$ berada di bawah MSL (mean sea leve), sehingga tambak tidak mengalami kesulitan dalam hal pemasukan air, akan tetapi sebaliknya bermasalah pada saat proses pengeringan. Dari 108 petak tambak yang terukur, terdiri atas 32 kepemilikan lahan. Kondisi mangrove masih cukup baik menjadi penyangga areal pertambakan dari erosi pantai dan luapan air Sungai Tui yang terjadi setiap tahunnya. Diperkirakan $88 \%$ dari luasan tambak sedang berproduksi yang bervariasi dari tambak yang dikelola secara intensif $(5 \%)$, semi intensif $(10 \%)$, hingga tradisional (85\%), dan komoditas yang sementara dikembangkan dan terlihat cukup baik adalah bandeng (Chanos chanos), rumput laut (Gracillaria sp.), dan mujair (Tilapia sp.), sementara $22 \%$ tidak berproduksi.

Permasalahan utama yang sedang dihadapi dalam kegiatan budi daya adalah masalah kualitas fisik dan kimia air tambak yang fluktuatif seiring dengan perubahan musim, kualitas tanah yang masih tergolong tanah muda (bergambut) sering menyulitkan masalah teknis. Masalah yang tidak kalah penting lainnya adalah tingkat kemasaman tanah yang dapat dilihat secara umum dari selisih $\mathrm{pH}_{\mathrm{F}}$ dan $\mathrm{pH}_{\mathrm{FOx}}$, reaksi peroksida, potensial redoks, warna, dan tekstur tanah (Tabel 1). Pada kenyataannya hampir semua organisme akuatik membutuhkan $\mathrm{pH}$ minimal 6 untuk dapat bertahan hidup secara normal, $\mathrm{pH}$ untuk perairan yang tergolong masam dapat mencapai 2 dan kadangkadang 4. Ikan dan krustasea senantiasa berusaha untuk menghindari air yang masam, akan tetapi jika mereka tidak dapat menghindarinya maka kemungkinan akan mejadi penyebab kematiannya (Sammut, 1997; Sammut, 2000).

Nilai variabel $\mathrm{pH}_{\mathrm{F}}$ yang cukup tinggi menunjukkan tingkat kemasaman aktif tambak relatif rendah pada saat pengukuran, selanjutnya setelah dioksidasi dengan peroksida $\left(\mathrm{H}_{2} \mathrm{O}_{2}\right) 30 \%$ terjadi penurunan tajam hingga $\mathrm{pH}=1,62$. Hal ini menjadi informasi yang menarik tentang adanya potensi yang masih tersimpan dalam partikel tanah tambak yang sewaktuwaktu dapat bangkit jika didukung oleh kondisi alamiah (terekspos pada saat surut) atau karena perlakuan petani tambak (pengeringan dan penggalian). Namun demikian rentang nilai peroksida antara $1-3(1=$ reaksi kurang dan $3=$ reaksi kuat) yang bervariasi untuk setiap data masih menjadi tanda tanya, apakah secara umum (hampir semua petak) tambak tersebut memilki potensi kemasaman yang tinggi atau hanya karena adanya faktor-faktor kimia, fisik, dan biologis tertentu pada areal tambak tertentu.

Tabel 1. Hasil analisis kualitas tanah yang diambil secara acak pada areal survai

Table 1. Output analysis of soil quality were taken randomly at study site

\begin{tabular}{lcc}
\hline Peubah (Variables) & Rentang (Range) & Rata-rata (A verage) \\
\hline $\mathrm{pH}_{\mathrm{F}}$ & $6.91--7.43$ & 7.16 \\
$\mathrm{pH}_{\mathrm{FOX}}$ & $1.62--6.37$ & 3.04 \\
$\mathrm{pH}_{\mathrm{F}}-\mathrm{pH}_{\mathrm{FOX}}$ & $5.29--1.06$ & 4.12 \\
$\mathrm{PR}$ & $1--3$ & 1.2 \\
Potensial Redoks & -23 hingga -386 \\
Redox potential & Lempung liat berpasir, liat berpasir, liat \\
Kelas tekstur & Sandy clay loam, sandy clay, clay \\
Textural classes & Abu-abu tua \\
Warna tanah & Dark greenish gray \\
Soil color &
\end{tabular}

$\mathrm{pH}_{\mathrm{F}}=\mathrm{pH}$ yang terukur langsung di lapangan dengan menggunakan $\mathrm{pH}$-meter $(\mathrm{pH}$ done in the field on saturated soil sample using $\mathrm{pH}$ probe)

$\mathrm{pH}_{\mathrm{FOX}}=\mathrm{pH}$ yang diukur di lapangan $-30 \%$ reaksi peroksida, menggunakan $\mathrm{pH}$ meter $(\mathrm{pH}$ measured in the field $30 \%$ peroxide reaction, $\mathrm{pH}$ probe)

$\mathrm{p}_{\text {HOX }}=\mathrm{pH} 1: 201 \mathrm{M} \mathrm{KCl}$ yang disaring setelah pemberian peroksida $(\mathrm{pH}$ of filtered 1:20 $1 \mathrm{M} \mathrm{KCl}$ after peroxide digestion)

$\mathrm{PR}=$ Reaksi Peroksida (Peroxide reaction) 


\section{Model Distribusi Potensi Kemasaman dengan Referensi Pelataran Tambak}

Model ini berasumsi bahwa permukaan tambaktambak memiliki ketinggian yang sama, sehingga titik nol pengukuran ditetapkan terletak pada dasar pelataran tambak. Hasil klasifikasi data berdasarkan rentang kedalaman dari dasar pelataran tambak dianggap sebagai suatu populasi dengan jumlah $\mathrm{N}$ untuk uji statistik. Analisis deskriptif dengan memanfaatkan software pengolah data statistik SPSS untuk permukaan $0-20 \mathrm{~cm}$ pada beberapa variabel kunci yang menunjukkan potensi kemasaman disajikan pada Tabel 2.

Data tersebut lebih jauh menjelaskan bahwa dalam 1 ton tanah tambak pada kedalaman $0-20 \mathrm{~cm}$ dari dasar pelataran tambak, dapat menghasilkan 67,50$519,50 \mathrm{~mol} \mathrm{H}^{+} /$ton tanah tambak yang berpotensi menyebabkan kemasaman yang cukup tinggi $(\mathrm{pH}=$ $1,87)$. Kemasaman tersebut dapat terjadi secara parsial pada tiap petak tambak sesuai dengan analisis standar deviasi yang memiliki nilai yang tinggi. Dengan demikian untuk kedalaman homogen $(0-20 \mathrm{~cm})$, ada faktor horizontal (keruangan) yang menjadi penyebab tingginya potensi kemasaman tanah. Hal ini dapat diketahui lebih lanjut pada peta distribusi variabelvariabel tanah berikut (Gambar 3). Potensi kemasaman yang tinggi dengan indikator selisih $\mathrm{pH}_{\mathrm{F}}$ dan $\mathrm{pH}_{\mathrm{FOX}}$ tersebar secara merata pada tambaktambak yang berjarak lebih jauh dari laut dan tersebar secara parsial pada tambak-tambak dekat laut, meski potensi kemasaman lebih tinggi terlihat pada daerah yang memiliki mangrove yang cukup tebal.
Begitu pula sebaran potensi kemasaman dengan indikator TPA dan \% pyrit terlihat memiliki kecenderungan yang sama, di mana potensi kemasaman yang tinggi lebih lebar terkonsentrasi pada daerah yang berjarak jauh dari garis pantai dan mulai tidak nampak pada daerah yang lebih dekat dengan garis pantai, hal ini disebabkan proses pencucian oleh pasut harian lebih intensif di daerah pantai. Potensi kemasaman yang tinggi pada daerah mangrove adalah potensi kemasaman total yang didukung oleh tingginya kandungan bahan organik pada daerah tersebut serta sedikit berasal dari pyrit yang terbentuk pada kondisi anaerob (terendam) dan karena kurang lancarnya proses pembilasan oleh fluktuasi pasut. Demikian halnya potensi kemasaman yang tinggi pada daerah yang berjarak cukup jauh dengan garis pantai, juga dijumpai pada daerah pertambakan dengan kondisi lahan yang senantiasa tergenang (umumnya pada tambak-tambak di sekitar saluran air) dan jarang terekspos dengan periode waktu yang lama pada saat surut.

Dengan demikian distribusi potensi kemasaman lahan tambak dengan model pendekatan kedalaman sampel terukur dari pelataran tambak nampaknya membentuk pola yang seirama dengan alur genangan air pasut untuk periode yang cukup lama baik karena perlakuan budi daya (penggalian dan pembuatan pematang) ataupun karena kondisi alami lahan yang senantiasa tergenang.

Banyak faktor yang mempengaruhi kemasaman tanah, umumnya adalah iklim, siklus hidrologi, vegetasi, batuan-batuan induk, dan manusia yang memegang peranan penting dalam mempengaruhi kemasaman (Bear, 1964).

Tabel2. Hasil analisis statistik deskriptif pada kategori sampel kedalaman 0-20 cm dari pelataran tambak

Table 2. Output analysis of descriptive statistic at each sample variables, depth layer $0-20 \mathrm{~cm}$ measured from pond bottom

\begin{tabular}{lrrrrr}
\hline $\begin{array}{c}\text { Peubah } \\
\text { Variables }\end{array}$ & N & $\begin{array}{c}\text { Minimum } \\
\text { Minimum }\end{array}$ & $\begin{array}{c}\text { Maksimum } \\
\text { Maximum }\end{array}$ & $\begin{array}{l}\text { Rata-rata } \\
\text { Average }\end{array}$ & $\begin{array}{c}\text { Standar deviasi } \\
\text { Standard deviation }\end{array}$ \\
\hline PHF $_{\mathrm{F}} \mathrm{pH}_{\mathrm{FOX}}$ & 108 & 1.02 & 5.45 & 4.317 & 1.1762 \\
$\mathrm{pH}_{\mathrm{OX}}$ & 108 & 1.87 & 4.28 & 2.767 & 0.4974 \\
$\mathrm{TPA}$ & 108 & 67.50 & 519.50 & 228.379 & 81.3045 \\
STPA & 108 & 0.11 & 0.83 & 0.366 & 0.1304 \\
\% Pyrit & 108 & 0.28 & 2.31 & 1.012 & 0.3646 \\
\hline
\end{tabular}

\footnotetext{
$\mathrm{pH}_{\mathrm{F}} \quad \mathrm{=} \mathrm{pH}$ done in the field on saturated soil sample using $\mathrm{pH}$ probe

$\mathrm{pH}_{\text {FOX }}=\mathrm{pH}$ measured in the field $-30 \%$ peroxide reaction, $\mathrm{pH}$ probe

$\mathrm{pH}_{\mathrm{OX}} \quad \mathrm{pH}$ of filtered $1: 201 \mathrm{M} \mathrm{KCl}$ after peroxide digestion $\begin{aligned} \text { TPA }= & \text { Total Potential Acidity in } 1 \mathrm{M} \mathrm{KCL} \text { peroxide digest titrated to } \mathrm{pH} 5.5 \text { Adopted from Peroxide Oxidation } \\ & \text { Combined Acidity \& Sulfate (POCAS) method }\end{aligned}$

STPA = TPA calculated as equivalent pyrite S\%S

$\%$ pyrite $=T S A / 22.4 * 0.1$

$\mathrm{N} \quad=$ Number of samples
} 

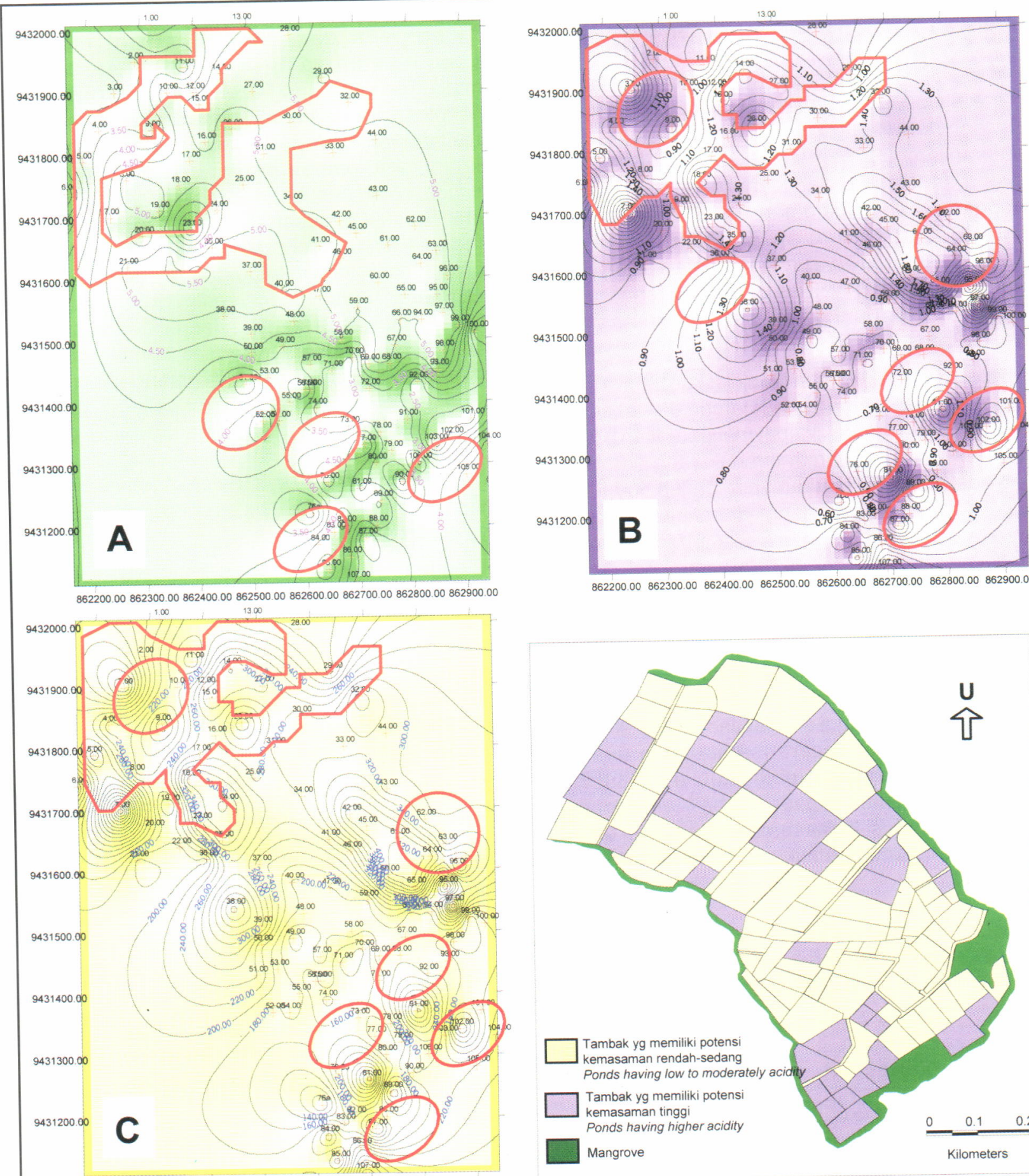

86220000862300.00862400 .00862500 .00862600 .00862700 .00862800 .00862900 .00

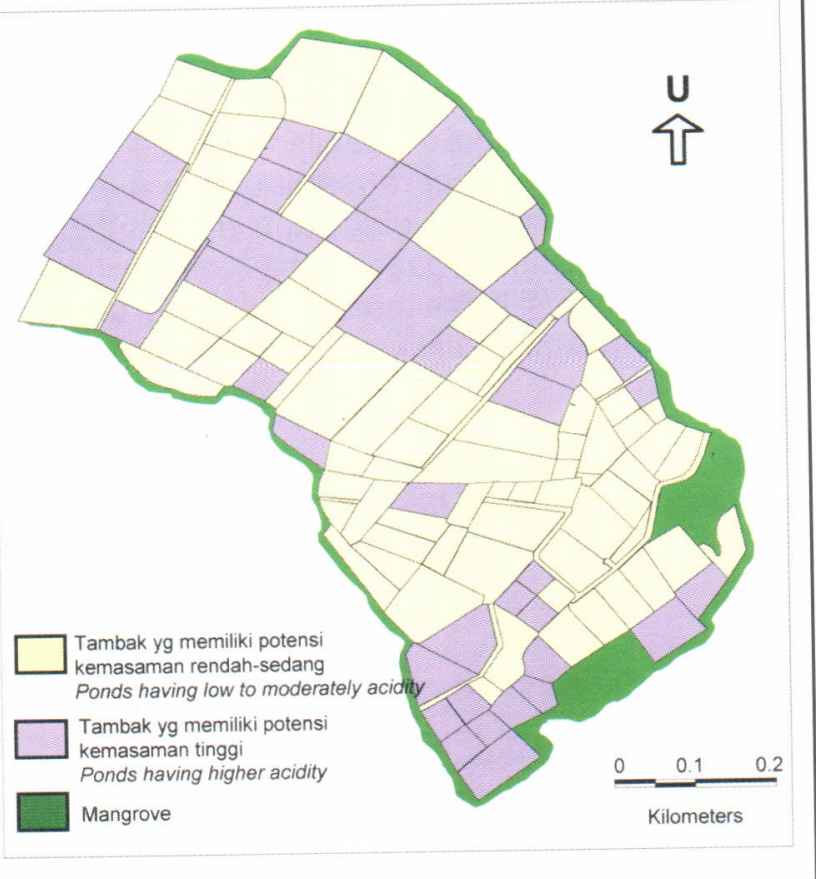

Gambar 2. Peta distribusi potensi kemasaman lahan pertambakan pada lapisan kedalaman $0-20 \mathrm{~cm}$ yang terukur dari pelataran tambak $\left(\mathrm{A}=\mathrm{pH}_{\mathrm{F}}-\mathrm{pH}_{\mathrm{FOX}}, \mathrm{B}=\% \mathrm{Pyrit}, \mathrm{C}=\mathrm{TPA}\right)$

Figure 2. Map of acidity distribution model of the pond area at the depth range $0-20 \mathrm{~cm}$ measured from pond bottom $\left(A=\mathrm{pH}_{\mathrm{F}}-\mathrm{pH} \mathrm{H}_{\mathrm{FOX}}, \mathrm{B}=\%\right.$ pyrite, $\left.C=T P A\right)$

Jika pada kondisi tambak demikian akan diaplikasikan teknik remediasi (pengapuran) untuk menetralkan total potensi kemasaman yang ada, maka kebutuhan kapur dapat diestimasi dengan pendekatan seperti yang dijelaskan oleh Ahern \& Blunden (1998) bahwa untuk $1 \mathrm{~mol} \mathrm{Ca} \mathrm{CO}_{3}$ akan menetralkan $2 \mathrm{~mol} \mathrm{H}^{+}\left(1 \mathrm{~mol} \mathrm{Ca} \mathrm{CO}_{3}=100,0872 \mathrm{~g}\right), 1$ mol $\mathrm{H}_{2} \mathrm{SO}_{4}$ adalah ekuivalen dengan $2 \mathrm{~mol} \mathrm{H}^{+}$, 
sehingga 1 bagian $\mathrm{CaCO}_{3}=1$ bagian $\mathrm{H}_{2} \mathrm{SO}_{4}$ (berat). Untuk nilai rata-rata TPA (hasil Tabel 2) adalah 228,37 $\mathrm{mol} \mathrm{H}$ /ton, maka akan dibutuhkan sebanyak 114,185 mol $\mathrm{CaCO}_{3}$ atau $11,428 \mathrm{~kg} \mathrm{CaCO}_{3}$ untuk menetralkan rata-rata 1 ton tanah tambak tersebut.

\section{Model Distribusi Potensi Kemasaman Berdasarkan Datum Referensi Lokal}

Berbeda dengan metode yang pertama, model ini mempertimbangkan kondisi topografi (kemiringan pantai) sebagai faktor yang dapat mempengaruhi secara signifikan potensi kemasaman di areal pertambakan, karena pada kenyataannya letak tambak bervariasi terhadap zonasi pasang surut (subtidal, intertidal, dan supratidal), sehingga perbedaan kondisi tersebut juga akan mempengaruhi konsentrasi senyawa kimia seperti pyrit $\left(\mathrm{FeS}_{2}\right)$.

Datum referensi berupa bench mark (BM) yang memiliki posisi horizontal (lintang dan bujur) yang terikat secara vertikal terhadap salah satu permukaan penting pasang surut (pasut) seperti Mean Low Water Neap (MLWN), Mean Low Water Spring (MLWS), Mean High Water Neap (MHWN), Mean High Water Spring (MHWS), Mean Sea Level(MSL), muka surutan peta (chart datum), akan menjadi kunci seluruh hasil pengukuran (vertikal dan horizontal) pada areal studi. Perbandingan beberapa nilai konstanta harmonik pasut yang diambil dari stasiun pengamatan pasut dekat dengan lokasi penelitian menunjukkan nilai amplitudo yang cukup bervariasi (Tabel 3) namun demikian dengan pertimbangan karakteristik umum.

Wilayah (letak geografis dan bentuk topografi) maka konstanta harmonik pasang surut untuk daerah Kolaka pada Tabel 3 dapat dijadikan acuan untuk mengetahui tipe pasut di daerah penelitian. Dari hasil perhitungan didapatkan nilai $F=0,811$, dengan demikian tipe pasang surut adalah campuran dengan tipe ganda lebih menonjol. Untuk tipe pasut demikian, selanjutnya dapat diprediksi letak berbagai macam permukaan penting pasang surut seperti yang diformulasi dalam Tabel 4.

Dalam analisis selanjutnya, yang akan digunakan sebagai acuan adalah MSL, sehingga letak vertikal sampel seluruhnya akan terkoreksi terhadap permukaan pasut penting tersebut. Pengikatan data pada titik acuan ini akan didapatkan kondisi topografi pada areal studi seperti yang diilustrasikan pada Gambar 4. Kondisi topografi lahan tambak pada areal studi yang terbentuk secara alami dan akibat perlakuan budi daya (pendalaman dasar tambak) umumnya didominasi lahan yang tergolong subtidal hingga inter-

Tabel 3. Nilai konstanta hasil prediksi pasut untuk stasiun pengukuran di sekitar area studi

Table 3. Predicted tidal constituents value in the study site neighborhood of stations

\begin{tabular}{|c|c|c|c|}
\hline \multirow{2}{*}{$\begin{array}{c}\text { Komponen } \\
\text { harmonik pasut } \\
\text { Tidal constituents }\end{array}$} & \multicolumn{2}{|c|}{$\begin{array}{l}\text { Lokasi } \\
\text { Location }\end{array}$} & \multirow{2}{*}{$\begin{array}{l}\text { Keterangan } \\
\text { Notes }\end{array}$} \\
\hline & Makassar & Kolaka & \\
\hline M2 & 8 & 55 & $\begin{array}{l}\text { Amplitudo komponen pasut ganda utama yang } \\
\text { disebabkan oleh gaya tarik bulan }\end{array}$ \\
\hline S2 & 11 & 14 & $\begin{array}{l}\text { The principal lunar semi-diurnal components } \\
\text { Amplitudo komponen pasut ganda utama yang } \\
\text { disebabkan oleh gaya tarik matahari } \\
\text { Principlal solar semi-diurnal components }\end{array}$ \\
\hline N2 & - & 10 & $\begin{array}{l}\text { Principlal solar semi-diurnal components } \\
\text { Komponen akibat variasi bulanan jarak bumi- } \\
\text { bulan }\end{array}$ \\
\hline $\mathrm{K} 2$ & 5 & 4 & $\begin{array}{l}\text { Lunar elliptic semi-diurnal constituents } \\
\text { Komponen matahari-bulan akibat perubahan } \\
\text { sudut deklinasi matahari-bulan }\end{array}$ \\
\hline $\mathrm{K} 1$ & 28 & 34 & $\begin{array}{l}\text { Lunar declination semi-diumal constituents } \\
\text { Amplitudo komponen pasut tunggal utama yang } \\
\text { disebabkan oleh gaya tarik bulan dan matahari } \\
\text { Luni-solar diurnal component }\end{array}$ \\
\hline O1 & 17. & 22 & $\begin{array}{l}\text { Amplitudo komponen pasut tunggal utama yang } \\
\text { disebabkan oleh gaya tarik bulan }\end{array}$ \\
\hline P1 & 11 & 11 & $\begin{array}{l}\text { Principal lunar diurnal component } \\
\text { Komponen utama diurnal matahari } \\
\text { Solar declination diurnal constituents }\end{array}$ \\
\hline
\end{tabular}


Tarunamulia, Tangko, A.M., dan Hanafi, A.

Tabel 4. Ketinggian beberapa permukaan penting pasut dengan referensi MSL

Table 4. The level of some tide important surfaces referenced to MSL

\begin{tabular}{lcc}
\hline $\begin{array}{c}\text { Bidang } \\
\text { References level }\end{array}$ & $\begin{array}{c}\text { Formula yang digunakan } \\
\text { Formula used }\end{array}$ & $\begin{array}{c}\text { Ketinggian (cm) } \\
\text { Level }(\mathbf{c m})\end{array}$ \\
\hline HAT & $\mathrm{MSL}+(\mathrm{AM} 2+\mathrm{AS2}+\mathrm{AK} 1+\mathrm{AO} 1)$ & 64 \\
MHWS & $\mathrm{MSL}+(\mathrm{AM} 2+\mathrm{AS} 2)$ & 19 \\
MHWN & $\mathrm{MSL} \pm(\mathrm{AM} 2-\mathrm{AS} 2)$ & 3 \\
MSL & & \\
MLWN & $\mathrm{MSL} \pm(\mathrm{AM} 2-\mathrm{AS} 2)$ & -3 \\
MLWS & $\mathrm{MSL}-(\mathrm{AM} 2+\mathrm{AS} 2)$ & -19 \\
chat datum & $\mathrm{MSL}-(\mathrm{AM} 2+\mathrm{AS} 2+\mathrm{AK} 1+\mathrm{AO} 1)$ & -64 \\
\hline
\end{tabular}

Sumber (Sources) : Pugh (1987) and Tarunamulia (1999)

Keterangan (Note) : Mean Low Water Neap (MLWN), Mean Low Water Spring (MLWS), Mean High Water Neap (MHWN), Mean High Water Spring (MHWS), Mean Sea Level (MSL), muka surutan peta (chart datum)

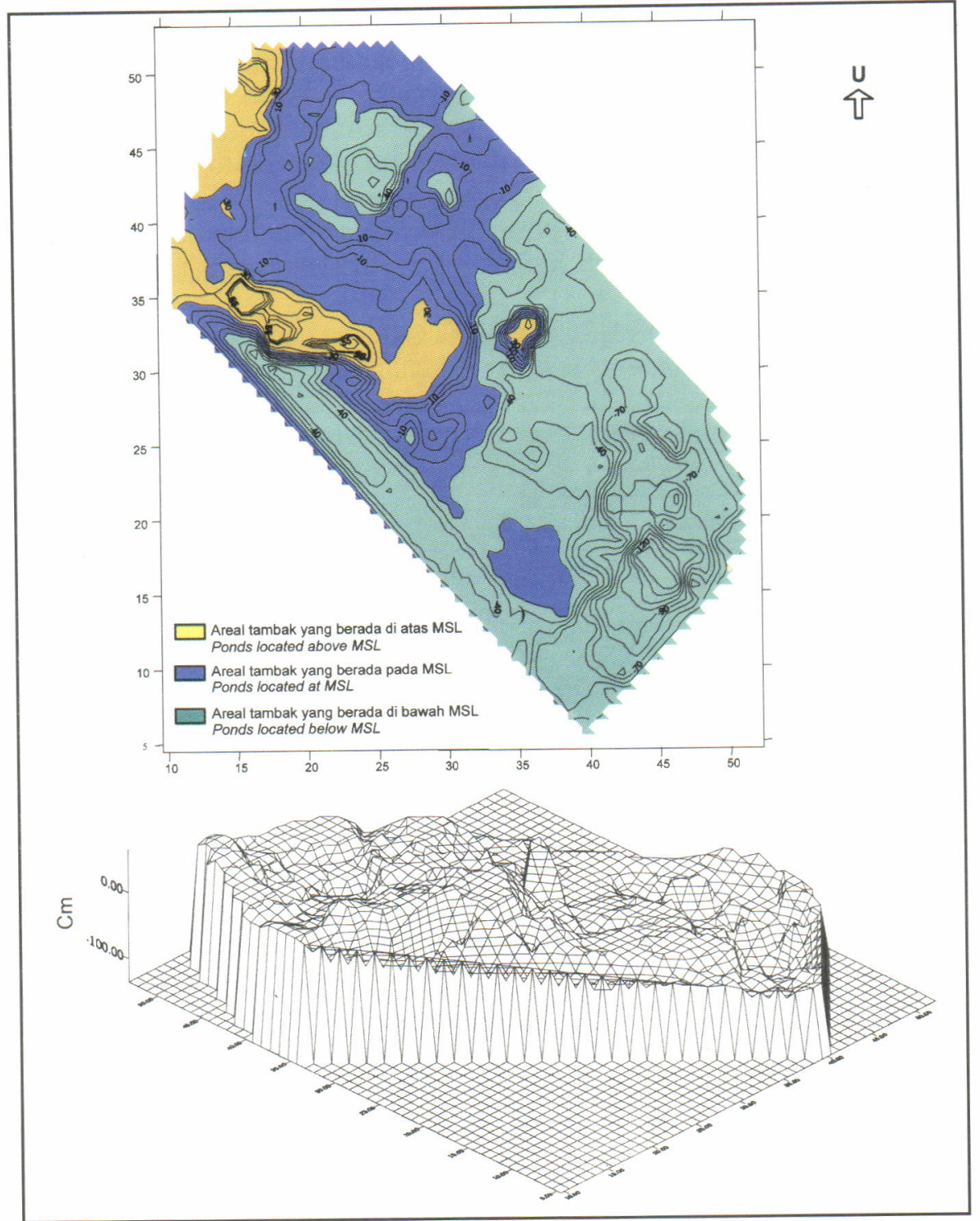

Gambar 3. Bentuk topografi areal tambak yang dianalisis dari hasil pengkuran Figure 3. Pond bottom relief created from the data analyses of measurement 
tidal (umumnya berada di bawah MSL), sehingga memungkinkan terbentuknya lapisan pyrit. Menurut Breemen (1982), pada kondisi lahan yang ditutupi oleh hutan mangrove, jenuh air, dan adanya sulfat dari laut memungkinkan terbentuknya pyrit apalagi jika besi oksida $\left(\mathrm{Fe}_{2} \mathrm{O}_{3}\right)$ atau besi sulfida ( $\mathrm{FeS}$ ) cukup tersedia.

Distribusi potensi kemasaman terkonsentrasi pada daerah yang sama dengan model yang pertama meskipun nampak lebih lebar terutama pada daerah yang berlokasi lebih jauh dari garis pantai (Gambar 5). Rendahnya potensi kemasaman pada daerah dekat garis pantai disebabkan adanya proses pembilasan yang sangat efektif hingga pada kedalaman sampel tanah $(0-20 \mathrm{~cm})$, sedangkan untuk tambak lebih jauh dengan garis pantai dengan elevasi di atas MSL, proses pembilasan tidak akan terlalu mempengaruhi
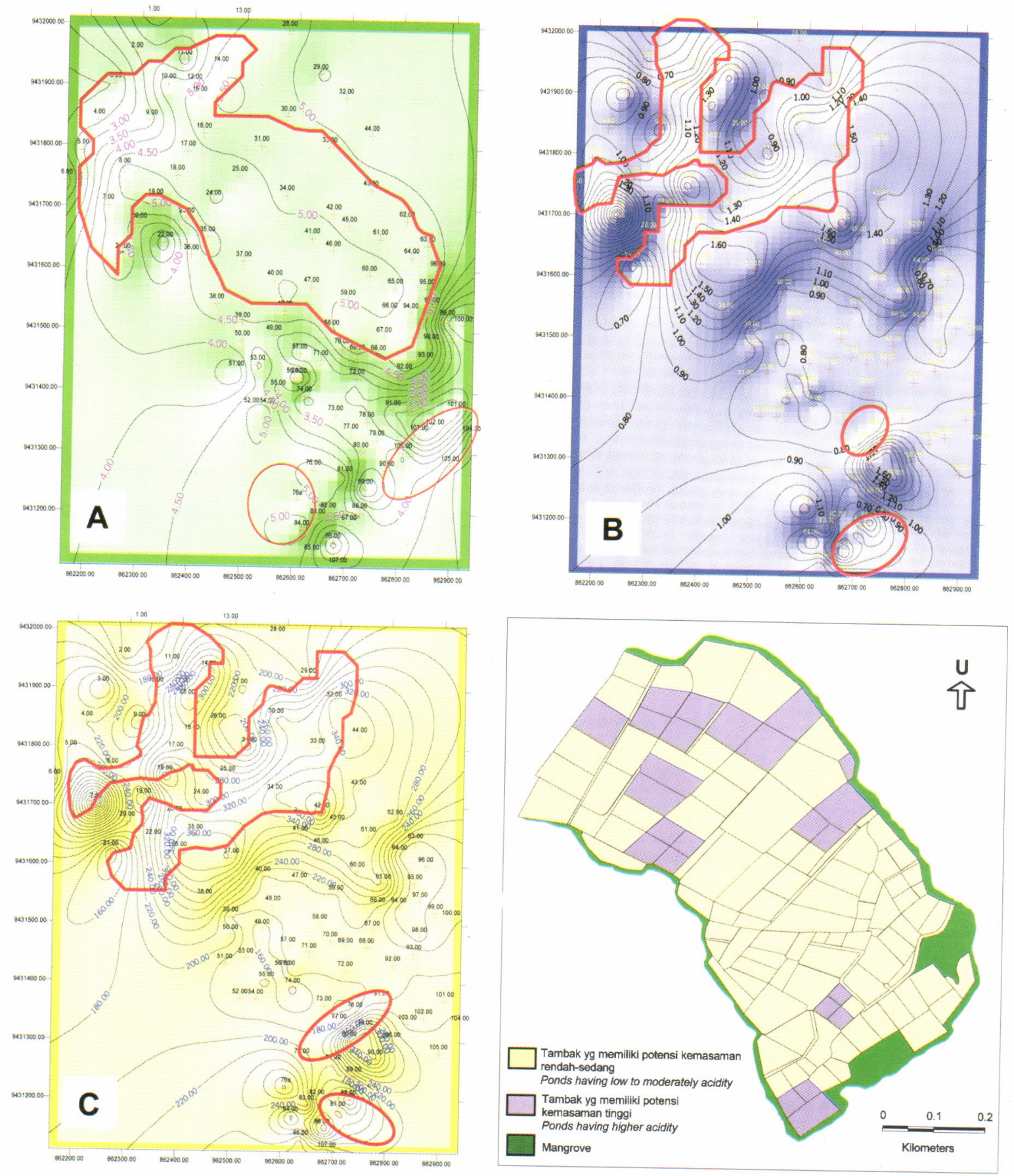

Gambar 4. Peta distribusi potensi kemasaman lahan pertambakan pada lapisan kedalaman $0-20 \mathrm{~cm}$ yang terukur MSL $\left(\mathrm{A}=\mathrm{pH}_{\mathrm{F}}-\mathrm{pH}_{\mathrm{FOX}}, \mathrm{B}=\%\right.$ Pyrit, $\left.\mathrm{C}=\mathrm{TPA}\right)$

Figure 4. Map of acidity distribution models of the pond area at the depth range of $0-20 \mathrm{~cm}$ measured from MSL 
potensi kemasaman yang ada. Di samping itu pengambilan sampel lebih dalam dilakukan untuk mendapatkan lapisan homogen $0-20 \mathrm{~cm}$ dari MSL, sehingga kondisi tanah betul-betul menunjukkan nilai potensial redoks negatif (anaerob) dan tidak terganggu. Hal ini juga dapat dibuktikan dari hasil analisis statistik deskriptif yang menunjukkan nilai rata-rata $\mathrm{pH}_{\mathrm{F}}-\mathrm{pH}_{\mathrm{FOX}}$, TPA, STPA, dan \% pyrit yang lebih tinggi dari model pertama (Tabel 5).

Dengan analisis yang sama untuk nilai rata-rata TPA pada Tabel 5, maka setidaknya dibutuhkan sebanyak 120,31 mol atau $12,04 \mathrm{~kg} \mathrm{CaCO}_{3}$ untuk menetralkan rata-rata 1 ton tanah tambak tersebut.

\section{Korelasi antara Kedua Model distribusi}

Dari hasil analisis korelasi menggunakan software statistik SPSS, diketahui bahwa arah korelasi antara masing-masing variabel bersesuaian memiliki tanda positif yang menandakan adanya hubungan, begitu pula signifikasi hasil korelasi antara dua variabel bersesuaian tersebut menunjukkan semua nilai probabilitas lebih kecil dari 0,05 dan 0,01, sehingga semua pasangan variabel yang diuji secara nyata berkorelasi. Akan tetapi nilai korelasi Pearson yang rata-rata memiliki nilai lebih kecil dari 0,5 menunjukkan bahwa hubungan tersebut tidak kuat akibat perlakuan,

Tabel 5. Hasil analisis statistik deskriptif pada kategori sampel kedalaman 0-20 cm di bawah MSL

Table 5. Output analysis of decriptive statistic at each sample variables, depth of $0-20 \mathrm{~cm}$ below MSL

\begin{tabular}{lrrrrr}
\hline $\begin{array}{c}\text { Peubah } \\
\text { Variables }\end{array}$ & N & $\begin{array}{c}\text { Minimum } \\
\text { Minimum }\end{array}$ & $\begin{array}{c}\text { Maksimum } \\
\text { Maximum }\end{array}$ & $\begin{array}{c}\text { Rata-rata } \\
\text { Mean }\end{array}$ & $\begin{array}{c}\text { Standar deviasi } \\
\text { Standard deviation }\end{array}$ \\
\hline $\mathrm{pH}_{F}-\mathrm{pH}_{\text {FOX }}$ & 108 & 1.02 & 5.54 & 4.3449 & 1.1200 \\
$\mathrm{PH}_{\mathrm{OX}}$ & 108 & 1.87 & 4.28 & 2.7045 & 0.4839 \\
$\mathrm{TPA}$ & 108 & 67.50 & 519.50 & 240.6250 & 93.9846 \\
STPA & 108 & 0.11 & 0.83 & 0.3858 & 0.1507 \\
$\%$ Pyrit & 108 & 0.30 & 2.31 & 1.0666 & 0.4177 \\
\hline
\end{tabular}

Tabel 6. Hasil analisis korelasi antara variabel yang bersesuaian untuk model yang berbeda Table 6. Output analysis of variables correlation at different reference models

\begin{tabular}{|c|c|c|c|c|c|c|c|}
\hline $\begin{array}{c}\text { Peubah } \\
\text { Variabels }\end{array}$ & & $\begin{array}{c}\mathrm{PH}_{\mathrm{F}}-\mathrm{pH} \\
\text { (MSL) }\end{array}$ & $\begin{array}{l}\mathrm{pH}_{\mathrm{ox}} \\
\text { (MSL) }\end{array}$ & $\begin{array}{c}\text { TPA } \\
\text { (MSL) }\end{array}$ & $\begin{array}{l}\text { STPA } \\
\text { (MSL) }\end{array}$ & $\begin{array}{c}\mathrm{S}_{\text {TSA }} \\
\text { (MSL) }\end{array}$ & $\begin{array}{c}\text { \% pyrite } \\
\text { (MSL) }\end{array}$ \\
\hline \multirow[t]{3}{*}{$\mathrm{PH}_{\mathrm{F}}-\mathrm{pH}_{\text {FOX }}$} & Pearson Correlation & $0.659^{\star *}$ & & & & & \\
\hline & Sig. (2-tailed) & 0 & & & & & \\
\hline & $N$ & 108 & & & & & \\
\hline \multirow{2}{*}{$\mathrm{pH}_{\mathrm{Ox}}$} & Pearson Correlation & & $0.433^{* *}$ & & & & \\
\hline & Sig.(2-tailed) & & 0 & & & & \\
\hline \multirow[t]{3}{*}{ TPA } & $\mathrm{N}$ & & 108 & & & & \\
\hline & Pearson Correlation & & & $0.471^{*}$ * & & & \\
\hline & $\begin{array}{l}\text { Sig.(2-tailed) } \\
\mathrm{N}\end{array}$ & & & 0 & & & \\
\hline \multirow[t]{3}{*}{ STPA } & Pearson Correlation & & & 108 & & & \\
\hline & $\begin{array}{l}\text { Pearson Correlation } \\
\text { Sig. (2-tailed) }\end{array}$ & & & & $0.477^{* *}$ & & \\
\hline & $\begin{array}{l}\text { Slg.(2-talied) } \\
\mathrm{N}\end{array}$ & & & & $\begin{array}{r}0 \\
108\end{array}$ & & \\
\hline \multirow{3}{*}{$\mathrm{S}_{\mathrm{TSA}}$} & Pearson Correlation & & & & & $0.483^{*} *$ & \\
\hline & Sig.(2-tailed) & & & & & 0 & \\
\hline & $\mathrm{N}$ & & & & & 108 & \\
\hline \multirow[t]{3}{*}{$\%$ pyrite } & Pearson Correlation & & & & & & $0.483^{\star \star}$ \\
\hline & Sig.(2-tailed) & & & & & & 0 \\
\hline & $\mathrm{N}$ & & & & & & 108 \\
\hline
\end{tabular}

** Hubungan nyata pada level 0,01 (Correlation is significant at the 0.01 level (2-tailed)

* Hubungan nyata pada level 0,05 (Correlation is significant at the 0.05 level (2-tailed) 
hanya hubungan antara selisih $\mathrm{pH}_{F}$ dengan $\mathrm{pH}_{\mathrm{FOX}}$ yang masih memiliki hubungan kuat (Tabel 6).

Hal ini dapat dijelaskan karena pada kenyataannya tambak merupakan lahan yang sudah mengalami perlakuan (penggalian dasar, penyekatan, dan berbagai macam perlakuan budi daya), sehingga tentunya memiliki sifat-sifat yang lebih kompleks dibandingkan dengan lahan asli yang belum dimanfaatkan untuk suatu peruntukan khusus. Pada kedua analisis terdahulu, terlihat bahwa lahan tambak tidak dapat ditinjau dengan pendekatan kecenderungan global, akan tetapi variasi lokal nampak lebih dominan akibat berbagai perlakuan seperti yang telah dijelaskan di atas. Penyebab lain yang dapat mempengaruhi hasil analisis adalah karena secara umum letak vertikal tambak lebih banyak berada di bawah MSL, sehingga variasi data sangat kecil, begitu pula kemiringan relatif lahan hampir $0 \%$ (datar). Namun demikian adanya kecenderungan pergeseran nilai potensi kemasaman tersebut harus diperhatikan bila suasana jauh berbeda (kemiringan tajam, jenis lahan asli, dan letak vertikal dari pasut yang bervariasi), karena hasil analisis statistik deskriptif menunjukkan perbedaan nilai yang cukup nyata antara kedua model pada posisi horizontal yang sama dengan ketinggian berada di atas MSL (analisis spesifik setelah data dikelompokkan). Perubahan tersebut terutama pada nilai rata-rata dan standar deviasi masing-masing variabel indikator potensi kemasaman.

\section{KESIMPULAN DAN SARAN}

Kedua model yang dibandingkan menggambarkan distribusi potensi kemasaman yang dipengaruhi oleh jenis penutup lahan, letak dari garis pantai, dan pola genangan air pasut. Tidak didapatkan adanya perbedaan dalam kenampakan model distribusi potensi kemasaman pada kedua model tersebut. Perbedaan yang menonjol hanya dapat dilihat pada data yang memiliki letak vertikal di atas MSL.
Perbedaan yang mengakibatkan nilai korelasi lemah terjadi terutama karena adanya beda letak vertikal sampel tanah dari perbedaan referensi pengukuran.

Kecenderungan dengan adanya perbedaan nilai tersebut harus menjadi perhatian dalam pengambilan sampel tanah, khususnya pada wilayah pesisir yang memiliki tingkat kemiringan yang tinggi dengan tunggang pasut yang rendah.

\section{DAFTAR PUSTAKA}

Ahern, C.R. and B. Blunden. 1998. Designing a soil sampling and analysis program. In Stone, Y., Ahern, C.R., and Blunden, B. (Eds.). Acid Sulfate Soils Manual. Acid Sulfate Soil Management Advisory Committee, Wollongbar, NSW, Australia, p. 21-25.

Bear, F. 1964. Chemistry of the Soil. Second edition, Oxford \& IBH Publishing Co. New Delhi Bombay Calcutta, India, p. 39-277.

Breeman, V.N. 1982. Genesis, morfology, and classification of acid sulfate soils in rcoastal plains part 111, p. 1-18 In Acid Sulphate Weathering. SSA Special Publ., No. 10. Soil Science Society of America, Madison, Wisconsin, p. 95-108.

DLWC (Department of land and water conservation). 1995. Guidelines for the Use of Acid Sulphate Soil Risk Maps. New South Wales (NSW), Sydney, Australia, 27: 5-15.

Pons, L.J., van Breeman, N., and Driessen, P.M. 1982. Physiography of coastal sediments and development of potential acidity part 1, In Acid Sulphate Weathering. Special Publ., Soil Science Society of America, Madison, Wisconsin, 10:1-18.

Pugh, D.T. 1987. Tide Surges and Mean Sea Level: $A$ Handbook for Engineers and Scientits. John Wiley and Sons. New York, 143: 121-132.

Sammut, J. 1997. Amelioration and Management of Shrimp Pond in Acid Sulfate Soils, Key Researchabel Issue. School of Geography, The University of New South Wales, Sydney, NSW 2052, Australia, p. 120-106.

Sammut, J. 2000. An Introduction to Acid Sulfate Soils. Australian Centre for International Agricultural Research (ACIAR) and NSW Acid Sulfate Soil Management Advisory committee, Sydney, 27: 8-17. 
